The 2012 Danish Presidency of the Council of the European Union Bridging Exclusion

Manners, Ian James

Published in:

Journal of Common Market Studies

DOI:

$10.1111 / \mathrm{jcms} .12056$

Publication date:

2013

Document version

Peer reviewed version

Citation for published version (APA):

Manners, I. J. (2013). The 2012 Danish Presidency of the Council of the European Union: Bridging Exclusion. Journal of Common Market Studies, 51(S1), 70-79. https://doi.org/10.1111/jcms.12056 


\title{
The 2012 Danish Presidency of the Council of the European Union: bridging exclusion
}

\author{
IAN MANNERS ${ }^{1}$ \\ University of Copenhagen
}

\section{Introduction}

"You're an out, a small out, and you're new. We don't want to hear from you." (Nicolas Sarkozy in Barker and Parker, 2011). ${ }^{2}$

Holding the rotating presidency of the Council of Ministers of the European Union (EU) is a challenging task for any Member State. But in the context of the global financial and Eurozone crisis, the perceived decline of EU influence in the world, and the growing resentment of EU citizens to austerity measures, the 2012 Danish Presidency of the EU was always going to be particularly difficult. As the remark from French President Nicholas Sakozy to newly-elected Danish Prime Minister Helle Thorning-Schmidt during the European Council meeting around 2am on Friday 9 December 2011 suggests, the Danish Presidency of the Council began early and in considerable difficulty (Gardner, 2012).

The Danish task was made even more demanding by the historical context of its relationship to the Treaty on European Union (TEU). However, the changes to the role of the rotating presidency introduced by the trios from 2007 and the Lisbon Treaty from 2009 held the potential to help overcome these difficulties. It would be simple to suggest that the newly elected centre-left government (after 10 years out of office) or the relative size of Danish governmental bureaucratic and diplomatic capacity were defining features of the presidency. But they were not.

Evaluating presidencies is never an easy task for both subjective and comparative reasons (see Manners, 2003; Quaglia and Moxon-Browne, 2006; Fernández, 2008; and Adler-Nissen, 2012a). Evaluations are subjective in the sense that ambition, expectation and impression are all important in our reading of presidencies. A balance has to be struck between internal evaluations of a 'pragmatic presidency' and external evaluations of an 'invisible presidency'. Comparative evaluations are exceptionally difficult, especially comparing historically with presidencies prior to the trio and Lisbon. In this respect, the Danish presidency could only conceivably be compared with the Spanish, Belgian, Hungarian and Polish presidencies that preceded it. The Danish presidency was a middle-member of the fourth trio since 2007, consisting of Poland-Denmark-Cyprus.

This assessment will examine three sides of the Danish presidency - its historical context, the Danish priorities, and the most difficult challenges. ${ }^{3}$ It will conclude that the presidency was largely a function of the political and economic context in which Denmark found itself during January to June 2012. This conclusion is broadly in line with the work of Fernández (2008) and Adler-Nissen (2012a) who argue that the role of presidency must be judged in terms of the defence of community interests rather than 'national interests'. In this context, the presidency appeared to perform relatively well in some areas such as administrative coordination, keeping some policies moving, and the interactive role of the Minister for European Affairs. The presidency appeared unable to do too much in areas which

\footnotetext{
${ }^{1}$ I am very grateful to the editors, Nathaniel Copsey and Tim Haughton, and in particular Rebecca Adler-Nissen, Mette Buskjær Christensen, Mads Dagnis Jensen, Dorte Sindbjerg Martinsen, Jens Ladefoged Mortensen, Peter Nedergaard, Julie Hassing Nielsen, and Marlene Wind for their help and comments.

2 The authenticity of this quote is uncertain with most sources referring to the Financial Times, but its validity is questioned. See also Charlemagne, 2012; Gardner, 2012; Kantner, 2012.

${ }^{3}$ For good empirical overviews of the presidency see Adler-Nissen et al, 2012; Jensen and Nedergaard, 2013; Buskjær Christensen and Nielsen, 2013; and the special issue of Økonomi \& Politik, 2012, 85:3 on 'Det danske EU-formandsskab foråret 2012'.
} 
were outside of its reach, such as the Eurozone, the budget or external action. The presidency appeared to encounter difficulty in areas that were a 'bridge too far', such as green growth, Schengen reform, and coordination within the trio. Could Denmark have performed better if it were a 'full member' of the EU? This is of course difficult to judge, but at least it would have stood a chance as a Eurozone member, which was not the case during 2012.

\section{Context: Danish Self-exclusions and the Lisbon Treaty}

More than any of the other 26 member states, the context of Denmark's historical relationship to the EU is critical in understanding its presidency. Denmark had a 40 year-relationship with the European institutions, it was entering its seventh presidency demonstrating it had plenty of positive experiences in the job. More importantly some of its crucial diplomatic players, including Secretary of State Claus Grube and Permanent Representative Jeppe Tranholm-Mikkelsen, had extensive knowledge and experience of the EU. Denmark's previous experience of holding the presidency in 2002 had been widely represented as a success, in particular for reaching agreement on enlargement of the EU (Friis, 2003). The changes since 2002 could not have been more striking - the Danish exclusions from the TEU (below), as well as the changes of EU enlargement, the trio and Lisbon Treaty, and the economic crisis had transformed Denmark's relationship to the EU (DIIS, 2008; Manners, 2011).

\section{Danish Self-Exclusions}

In 1993 the Danish government was forced to negotiate a series of opt outs from the TEU in the areas of the Economic and Monetary Union (EMU), Justice and Home Affairs (JHA) and in Security and Defence Policy (SDP). Up until 1999 these opt outs did not really matter in institutional terms because the third stage of EMU had not occurred, while cooperation in JHA and SDP remained largely intergovernmental (Manners, 2000). From 1999 all this changed for Danish membership as it moved from 'opt outs' to 'self-exclusion'. It is important to remember that the opt outs were the result of a referendum result, not the result of party politics or government initiative. Every Danish government since 1993 has wished to remove some or all of these opt outs in some way. Hence the term 'selfexclusion' is far more appropriate to describe the extent to which, after 1999 they exclude Denmark from the benefits of being a fuller policymaking member state (DIIS, 2008; Kantner, 2012). In this respect, Adler-Nissen has described Denmark as a 'quasi-member' (Adler-Nissen, 2012b, p. 131).

Denmark has maintained a fixed exchange rate policy against Germany's currency since 1982, pegged first to the D-Mark (1982-1999) and then to the Euro (1999-date). From 1979-1999 Denmark was a full member of the Exchange Rate Mechanism (ERM) with a target currency fluctuation band of plus or minus 2.25 per cent. In 1999 Denmark joined the ERM II system with a nominal fluctuation band of plus or minus 2.25 per cent - in practice the actual currency fluctuation band is less than 1 per cent against the Euro. There are four wider consequences of Denmark's exclusion from the third stage of EMU. First, many assume that the Danish Kroner is free floating, but it is actually pegged in a fixed exchange rate policy against the Euro - the 'Krone-uro' (Bentow, 2000). Second, the fixed exchange rate policy brings both economic benefits in terms of stability and the possibility of floating, but economic costs in terms of finance, investment and trade (Flam, 2009; Aabo and Pantzalis, 2011). Third, a political consequence is that Denmark is excluded from participation in the Eurogroup of finance ministers and full membership of the European Central Bank (Dyson and Marcussen, 2010). The final consequence was that while Denmark joined the Treaty on Stability, Coordination and Governance during its presidency, leadership on issues related to economic governance came from the four presidents of the European Council, Commission, Eurogroup and the European Central Bank (ECB).

Denmark participates to the fullest extent possible in the areas of JHA, although this was complicated as external border controls, asylum, immigration and the prevention and combating of crime were transferred to supranational policymaking an Area of Freedom, Security and Justice (AFSJ) (Manners, 
2000). ${ }^{4}$ Prior to the Lisbon Treaty, Denmark participated intergovernmentally in many areas of AFSJ, but was excluded from supranational policy making except for Schengen and areas of parallel agreement (e.g. the Dublin Regulation), where it aligns its national legislation on civil law and asylum with that of the EU. In other areas of AFSJ Denmark has unilaterally introduced similar rules under Danish law (Adler-Nissen and Gammeltoft-Hansen, 2010, p. 145). The Lisbon Treaty brought Police and Judicial Cooperation in Criminal Matters (PJCC) into EU supranational policy making with 'opt in' rules for the UK and Ireland. Denmark may change its exclusion to a more inclusive 'opt in' position through a referendum. The wider consequences of Denmark's exclusion from the supranational aspects of AFSJ include, first, the way Denmark participates in Schengen and parallel agreement areas as a taker, not maker of policy. Second, in other areas of border control, asylum, immigration and civil law, Denmark engages in the national shadowing of EU policies, but cannot lead on policies in these areas. Third, in police and criminal law Denmark could be systematically excluded as the Stockholm Programme slowly moves the AFSJ from intergovernmental to supranational legislation. However the indications from the European Asylum Support Office and other agreements suggested that Denmark seeks full status but winds-up with a hybrid observer/associate status similar to EFTA states (Comte, 2010; Monar, 2012). The final consequence was that whilst Denmark chaired the JHA council during its presidency, it did not participate on the same basis as the other Member States.

As a leading international advocate of the 'comprehensive approach' to international conflict, Denmark seeks to combine the civilian and military aspects of peacekeeping and conflict management. Denmark cannot do this in EU SDP as it is excluded from military cooperation within the EU's Common Foreign and Security Policy (CFSP). In general the Nordic influence on the development of civilian crisis management and civilian SDP has been relatively large (Björkdahl, 2008; Jakobsen, 2009). This exclusion has become more expansive with the growth of CFSP and CSDP activities over the past decade. It has also led to the withdrawal of Danish forces as NATO-led peacekeeping operations in Macedonia and Bosnia-Herzegovina became EU-led. Danish exclusion from the Nordic battlegroup and the European Defence Agency reflect two minor aspects of a much wider problem as the diplomatic, civilian and military aspects of SDP became integrated in the European External Action Service (EEAS) after the Lisbon Treaty. ${ }^{5}$ The wider consequences of Denmark's exclusion from SDP are four-fold. First, Denmark's ability to shape the post-Lisbon construction of the EEAS has been largely restricted to the activities of Poul Skytte Christoffersen and Michael Matthiessen, both of whom were international rather than national diplomats during 2010-2011. In contrast, fellow Nordic countries Sweden and Finland have senior staff in the EEAS as Director EU Intelligence Analysis Centre (EU INTCEN) and Chair of the Political and Security Committee, although neither country is a member of NATO. Second, EU SDP operations have increasingly involved the overlapping and interlaced deployment of military and civilian missions in regions such as the formerYugoslavia, Congo, Chad/Sudan, and Somalia. Third, EU SDP operations in the Somali regions such as EUNAVFOR - Operation Atalanta, EUTM Somalia and EUCAP NESTOR have been specifically aimed at improving maritime security critical for Danish shipping. Fourth, the combination of Danish exclusion from CSDP operations and the construction of the EEAS has enforced Denmark's NATO preference, for example in NATO air missions over Libya in 2011.

\section{The Trio of Poland-Denmark-Cyprus}

The Danish presidency was a middle-member of the fourth trio since 2007, consisting of PolandDenmark-Cyprus (PDC). Following the Spain-Belgium-Hungary trio, the Danish trio was the first post-Lisbon Treaty group to have two new presidencies in it. Furthermore, none of the members could be considered central players in Europe-wide attempts to deal with the crisis of the Eurozone. The PDC trio created some difficulties for Denmark as Poland was eager and ambitious in its first presidency, acting more like a larger state despite relative lack of experience (Pomorska and

\footnotetext{
${ }^{4}$ For developments in the realm of JHA in 2012 see Monar's contribution to this volume.

${ }^{5}$ For an overview of developments in EU foreign relations in 2012 see Hadfield and Fiott's contribution to this volume.
} 
Vanhoonacker 2012). In contrast, Cyprus had relatively little capacity and ambition, and was almost entirely consumed by banking crises and relations with Turkey. ${ }^{6}$ Despite these difficulties, initial administrative coordination with Poland was good, despite disagreements over green growth. However the trio resulted in little agreement on the 18-month Programme of the Council, which meant the work had to be done in the Council Secretariat, potentially weakening the trio agenda management role of the Presidency. The trio presidencies were intended to facilitate coordination and allow older members to help newer members. But the Eurozone crises completely overshadowed the PDC trio with Denmark not well placed to help, particularly Cyprus, in this respect. According to Jensen and Nedergaard, the trio had a 'moderate to low scope of goals as well as a moderate to low depth of coordination', compared with previous trios (Jensen and Nedergaard, 2013). However, also be argued that the process of drawing up the trio programme did have a socialising effect on the participants (Adler-Nissen, 2012a).

\section{The Lisbon Treaty Changes for Denmark}

The Lisbon Treaty changes regarding, in particular, the President of the European Council, the High Representative of the Union for Foreign Affairs and Security Policy, the EEAS, the legal basis of the Eurogroup, the consolidation of all areas of AFSJ in the supranational treaty base, and the enhanced status of the European Parliament, made the Danish Presidency radically different to all of those that preceded it (Beach, 2012). While these changes appear more immediate than those of the Danish exclusions, it is the combination that proved challenging for Denmark. The extent to which the President of the European Council ran the European Councils, the review of Eurozone governance (with the other three presidents), as well as seeking to steer the multi-annual financial framework (MFF) largely relegated the Danish presidency to a supporting role in the larger issues of the time. The three roles of the High Representative of the Union for Foreign Affairs and Security Policy in acting as foreign minister representing the EU with the help of the EEAS; chairing the Foreign Affairs council; and acting as deputy vice-president of the Commission raised a number of question over what role the Danish Foreign Minister, Villy Søvndal, was to play during the Danish Presidency. Similarly, EEAS diplomatic relations, delegations, operations, missions and negotiating roles brought together tasks formerly shared between the Commission, the Council Secretariat and the Presidency left less space for local Danish coordinating role in third countries. The Eurogroup was placed on a legal basis by the Lisbon Treaty which put it at the centre of attempts to shape EU economic governance, especially through the role of the President of the Eurogroup (one of the four presidents), excluding the Danish presidency from involvement. After the Lisbon Treaty, AFSJ policymaking, together with the consolidation and separation of tasks within Commission DG Justice (rights) and DG Home Affairs (free movement), moved beyond the policymaking fragmentation and lack of democratic oversight of the intergovernmental JHA and PJCC, especially through the Stockholm Programme. In this respect, the Danish presidency found itself chairing Council meetings discussing AFSJ policies it could not participate in on the same basis as other members. Finally, the Lisbon Treaty meant that the European Parliament experienced an increase in co-decision responsibility over areas including agriculture, immigration and the budget. Through these new powers the EP sought to extend its control of the Commission appointments, the High Representative, and the EEAS. To respond to this development the Danish Presidency created a Minister for European Affairs position and appointed Nicolai Wammen to the post.

\section{Priorities: A Responsible, Dynamic, Green and Safe Europe}

While the centrality of steering the MFF negotiations was known years in advance of the Danish presidency, the other priorities began to take shape about two years in advance. While Denmark has a long history of environmental advocacy, after the events of the Copenhagen UN Climate Change Conference of the Parties 15 in December 2009, and the appointment of Connie Hedegaard as European Commissioner for Climate Action in February 2010, it became clear that green growth

\footnotetext{
${ }^{6}$ For an account of the Cypriot Presidency see Christou's contribution to this volume.
} 
would be important to any Danish government holding the EU Presidency. However, this primary priority of green growth was soon overshadowed by the European sovereign-debt crisis, particularly that of Greece, during 2011. Hence by November 2011 the five main priorities of the Danish presidency were to be (i) overcoming the eurozone debt crisis; (ii) setting a new green growth agenda; (iii) making progress on negotiations over the EU's next MFF; (iv) making progress on justice and home affairs issues, including Schengen and asylum; (v) external matters, for example free trade agreements (Tranholm-Mikkelsen, 2011; Pop, 2011). The Danish Presidency priories were finalised late in December 2011 and publically presented in January 2012 (MFA, 2012a). The priorities were broadly similar to the Europe 2020 Strategy of smart, sustainable and inclusive growth: (i) Responsible Europe (economics); (ii) A Dynamic Europe (competitiveness); (iii) A Green Europe (green growth); and (iv) A Safe Europe (security). Not only had green issues dropped down the agenda, but issues which Denmark was excluded from (Eurozone and AFSJ) had risen up the agenda. It is also striking that unlike most presidencies, and especially compared with the focus on enlargement in the 2002 Danish Presidency, no real priority was given to external action. Like the Spanish, Belgian and Hungarian presidencies that proceeded it, the Danish Presidency demonstrated the effects of the Lisbon Treaty and the EEAS.

\section{A Responsible Europe}

The main focus of the EU during the Danish presidency was dealing with economic governance and Eurozone reform, areas in which Denmark played very little role in agenda management. It has been argued that for Finance Minister Margrethe Vestager, 'Denmark's position outside the eurozone meant that influence on economic and financial affairs was often only marginal and she remained a spectator as the group of 17 tried to get to grips with the crisis' (Gardner, 2012). As was clear since the Lisbon Treaty, and demonstrated by the conclusions of the March and June European Council meetings, agenda management of $A$ Responsible Europe was led by Herman Van Rompuy, the President of the European Council, together with presidents of the Commission, Eurogroup and the ECB. ${ }^{7}$ In contrast, the Danish presidency was generally acknowledged to have played a positive agenda management role in handling the MFF during the first half of 2012.

\section{A Dynamic Europe}

The secondary focus of the EU during the Danish presidency was the issue of addressing the Europe 2020 Strategy goal of 'smart growth' though revitalising the single market and developing a knowledge-based economy. In many respects this agenda has not changed since the 2000 Lisbon Strategy, although the low growth/high unemployment economic crises of 2012 raised this issue up the political agenda. Largely because of the flawed economics of austerity, for example in the reduction of research and investment in the draft MFF, the Danish presidency found very little opportunity for innovation in this long-standing weakness in EU policy. The one shining light, and unforeseen in the Danish priorities, was the surprise agreement on unified patent system reform.

\section{A Green Europe}

The priority of sustainable or green growth would have been an issue the presidency might have wanted to push hard on. Certainly Denmark was ambitious in the environmental area, especially on energy, chemicals, pollution, and the UN Rio+20 conference. While the presidency was successful in chemical regulation, ship pollution and Rio+20, it was blocked in energy efficiency reforms by heavyweight anti-green governments in the UK, Germany and Poland (EEB, 2012). Most unfortunately, the greatest opposition to the Danish presidency's advocacy of long-term climate and energy roadmaps 2050 appears to have come from its trio partner, Poland, although an unwillingness to push more at the international level also appeared to be a problem.

\section{A Safe Europe}

The Danish exclusions from the EU were also felt in the priority area of a safe Europe, particularly in the context of counter-terrorism and the civil war in Syria. While the Danish programme made no

\footnotetext{
${ }^{7}$ See Dinan's contribution to this volume.
} 
mention of a comprehensive approach, military or defence policies, the EU's crisis management concept was implemented in three new integrated civilian missions during the presidency: (i) EUCAP NESTOR (Horn of Africa); (ii) EUAVSEC South Sudan; and (iii) EUCAP Sahel Niger. The Danish Ministry of Foreign Affairs found itself struggling to describe the 'Adoption of a framework for more comprehensive approach in third countries' without using the terms military or defence (MFA, $2012 \mathrm{~b}$ ). These combined effects of the Lisbon Treaty changes to external representation and the Danish exclusions from the EU led to the observation that a safe Europe was not really a priority for the Danish presidency, or at best was overshadowed by the other priorities. However, as Dehousse and Menon (2006: 100) have argued 'a Presidency can only really accomplish objectives devised and set by others', thus it may be that Denmark may have sowed seeds for a more comprehensive approach to EU crisis management in the future.

\section{Challenges: Bridging exclusion}

This combination of rapidly changing context and externally-driven priories ensured that the 2012 Danish presidency of the EU was deeply challenging. But, was the presidency better or worse than others? As discussed, the presidency can only genuinely be compared with the four that preceded it. On these terms it can be favourably compared with the Belgian and Hungarian presidencies (Drieskens, 2011; Ágh, 2012), although it clearly had structural disadvantages compared to Belgium (despite its caretaker government) and advantages compared to Hungary (because of its repressive government). For all the reasons discussed, the presidency cannot be compared to the 2002 Danish presidency or the Spanish and Polish presidencies that preceded it. The Danish exclusions from the EU and the presidency strategy of focusing on the manageable and achievable tasks in the post-Lisbon era make such a comparison inappropriate. There are three conclusions that can be drawn from the presidency relating to the relatively successful bridge building activities, the largely out of reach areas of policy, and the very difficult areas which were a bridge too far for the Danish presidency.

\section{Bridge Building}

At its outset the Danish presidency was regularly portrayed as a 'bridge over troubled water' by both the Foreign Ministry and European press (Wammen, 2012). According to the Foreign Ministry the ambition of the presidency was to act as a bridge over troubled water and to demonstrate that cooperation works and is able to achieve results (Jensen, 2012). In this respect the presidency was relatively successful in the three bridge building activities of administrative coordination, the role of the Europe minister, and relations between Eurozone and non-Eurozone members. The presidency largely succeeded in coordinating the chairing activities of the Council of Ministers and bridging the administrative gaps between the trio (Jensen and Nedergaard, 2012). The Danish Minister for European Affairs Nicolai Wammen was able to provide coordination between ministries, member states, institutions and councils. Finally, the presidency was able to go some way towards bridging the large span between Eurozone and non-Eurozone members in the discussion of economic governance proposals and the 'two-pack' regulations on surveillance and monitoring the Euro area. The obvious comparison in this respect between Denmark, the UK and the Czech Republic helps illustrate the gaps.

\section{Out of Reach}

However, what was also clear to the Danish presidency was that a number of policy areas were largely out of reach of significant Danish agenda management and brokerage/mediation. One of these, the MFF, Denmark did its best to steer negotiations towards settlement in the future. But the two others, Eurozone governance and external action, were subject to Danish exclusions and the effects of the Lisbon Treaty, leaving them largely out of reach. The Eurozone was the dominant policy area during the Danish presidency, but the leading roles were taken by the four presidents, as well as important Euro-states such as Germany. The budget was the second most important policy area during the Danish presidency. However, the timing and inter-institutional dynamics meant that significant negotiations left it largely out of reach, although there is a feeling that the presentation of the negotiating box and discussions of Horizon 2020 were important. In the area of external action the 
ongoing events of the Arab uprisings (particularly Syria), bilateral trade negotiations, and continuing enlargement (Serbia) were important. In the post-Lisbon context, these areas were largely out of reach for the Danish presidency, although many of the secondary topics were manageable.

\section{Bridge too Far}

Unfortunately, there were a number of very difficult areas which were a bridge too far for the Danish presidency, although this perception came from outside, not inside the presidency. The Danish presidency ran into difficulties with its trio partner Poland on the low carbon roadmap to 2050, but also with green growth more generally. The Danish Justice Minister Morten Bodskov was attacked from many sides when he presented the unanimous decision of ministers for amendment to the Schengen Borders Code to the European Parliament. While this was a little unfair, given the strong pressure from France, Italy, the Netherlands and other Member States, there is a sense that as a Member State with special provisions for participation in JHA, the Danish presidency was being blamed for wider concerns about lack of EP democratic oversight. The EP suspended JHA cooperation with the Presidency until the next presidency, although Cyprus is not a member of Schengen. The lack of trio coordination in only the second post-Lisbon trio suggests problems for future trios. While some presidencies (such as Poland) still seek to run pre-Lisbon presidencies, others (such as Cyprus) experienced severe structural and capacity problems. This made Denmark's problems all the more challenging, particularly as the institutional diversity (EMU, JHA, SDP) between the trio was so striking.

The 2012 Danish-EU presidency was broadly in line with what informed outside observers had expected: an experienced, smaller Member State playing the role of EU president in a post-Lisbon environment, but with its hands tied behind its back. In many respects the Danish presidency played smart and went for the achievable; in some respects the advocates and critics of the presidency need to rethink what is achievable. Like all presidencies over the past five years, the 2012 Danish-EU presidency was not what it used to be. But then presidencies probably never were.

\section{References}

Aabo, T., and Pantzalis, C. (2011) 'In or Out: The Effect of Euro Membership on the Exercise of Real Business Options', European Journal of Finance, Vol. 14, No. 4, pp. 259-284.

Adler-Nissen, R. (2012a) 'Formandskabets prioriteter: Når EU’s dagsorden bliver en national ambition', Økonomi \& Politik, Vol. 85, No. 3, pp. 4-14.

Adler-Nissen, R. (2012b) 'Danish presidency risks being hoist on its referendum petard', Europe's World, Spring, p. 131.

Adler-Nissen, R., and Gammeltoft-Hansen, T. (2010) 'Straitjacket or Sovereignty Shield? The Danish Opt-Out on Justice and Home Affairs and Prospects after the Treaty of Lisbon' (Copenhagen: DIIS), pp. 137161.

Adler-Nissen, R., Nielsen, J. H. and Sørensen, C. (2012) The Danish EU Presidency 2012: A Midterm Report (Stockholm: Swedish Institute for European Policy Studies).

Ágh, A. (2012) 'The Hungarian Rhapsodies: The Conflict of Adventurism and Professionalism in the European Union Presidency', Journal of Common Market Studies, Vol. 50, No. s2, pp. 68-75.

Barker, A., and Parke, G. (2011) 'False assumptions underpinned British strategy', Financial Times, 16 December.

Beach, D. (2012) 'Fremtidens ledersløse formandskaber’, Økonomi \& Politik, Vol. 85, No. 3, pp. 63-74.

Bentow, D. (2000) 'Krone-uro', Børsen, 18 September.

Björkdahl, A. (2008) 'Norm advocacy: A small state strategy to influence the EU', Journal of European Public Policy, Vol. 15, No. 1, pp. 135-154.

Charlemagne (2012) 'To opt in or not to opt in: that is the question Denmark still wrestles with in the euro crisis', The Economist, 14 January.

Christensen, M. B. \& Nielsen, J. H. (2013), 'Can a Small Non-Euro Member State Holding the EU Presidency Make A Difference in Times of EU Economic Crisis', in P. Dabrowska-Klosinska. (ed.) Polish Yearbook of European Studies, vol. 15. 
Comte, F. (2010) 'A New Agency Is Born in the European Union: The European Asylum Support Office', European Journal of Migration and Law, Vol. 12, No. 4, pp. 373-405

Danish Institute for International Studies, DIIS (Ian Manners report coordinator) (2008) De danske forbehold over for den Europaiske Union: Udviklingen siden 2000 (Copenhagen: DIIS).

Dehousse, R., and Menon, A. (2009) 'The French Presidency', Journal of Common Market Studies, Vol. 47, No. s1, pp: 99-111.

Drieskens, E. (2011) 'Ceci n'est pas une présidence: The 2010 Belgian Presidency of the EU', Journal of Common Market Studies, Vol. 49, No. s1, pp. 91-102.

Dyson, K., and Marcussen, M. (2010) 'Transverse Integration in European Economic Governance: Between Unitary and Differentiated Integration', Journal of European Integration, Vol. 32, No. 1, pp. 17-39.

European Environmental Bureau, EEB (2012) The EEB's Assessment of the Environmental Dimension of the Danish Presidency of the European Union (Brussels: EEB).

Fernández, A. M. (2008) 'Change and Stability of the EU Institutional System: the Communitarization of the Council Presidency', Journal of European Integration, Vol. 30, No. 5, pp. 617-634.

Flam, H. (ed.) (2009) EMU at Ten: Should Denmark, Sweden and the UK Join? (Stockholm: Centre for Business and Policy Studies/SNS).

Friis, L. (2003) 'The Danish Presidency: 'Wonderful Copenhagen', Journal of Common Market Studies, Vol. 41, No. s1, pp. 49-51.

Gardner, A. (2012) 'A professional, pragmatic presidency', European Voice, 5 July.

Kantner, J.(2012) 'Dane seeks a Spot at Europe's Top Table', The New York Times, 11 January.

Jakobsen, P. V. (2009) 'Small States, Big Influence: The Overlooked Nordic Influence on the Civilian ESDP', Journal of Common Market Studies, Vol. 47, No. 1, pp. 81-102.

Jensen, C. S. (2012) 'The Danish EU Presidency 2012', presentation, 30 June.

Jensen, M. D., and Nedergaard, P. (2012) 'Erfolgreiche Koordination in turbulenten Zeiten: die dänische Ratspräsidentschaft im ersten Halbjahr 2012', Integration, Vol. 35, No. 4, pp. 258-273.

Manners, I. (2000) Substance and Symbolism: an Anatomy of Cooperation in the New Europe (Aldershot: Ashgate).

Manners, I. (2003) 'The British Presidency of 1998: New Labour, New Tone?' in O. Elgström (ed.) European Union Council Presidencies: A Comparative Analysis (London: Routledge), pp. 87-103.

Manners, I. (2011) 'Denmark and the European Union', in M. Wind and D. S. Martinsen (eds.) EU som et politisk system - Udviklinger og udfordringer (Copenhagen: Forlaget Columbus), pp. 178-95.

Ministry of Foreign Affairs, MFA (2012a) Europe at work: Programme of the Danish Presidency of the Council of the European Union 2012 (Copenhagen: MFA).

Ministry of Foreign Affairs, MFA (2012b) Europe at work: The results of the Danish Presidency of the Council of the European Union 2012 (Copenhagen: MFA).

Monar, J. (2012) The External Dimension of the EU's Area of Freedom, Security and Justice: Progress, potential and limitations after the Treaty of Lisbon, SIEPS Report 2012:1 (Stockholm: Swedish Institute for European Policy Studies).

Pomorska, K., and Vanhoonacker, S. (2012) 'Poland in the Driving Seat: A Mature Presidency in Turbulent Times', Journal of Common Market Studies, Vol. 50, No. s2, pp. 76-84.

Pop, V. (2011) Danish EU presidency to focus on euro crisis, EU Observer, 23 November.

Quaglia, L., and Moxon-Browne, E. (2006) 'What Makes a Good EU Presidency? Italy and Ireland Compared', Journal of Common Market Studies, Vol. 44, No. 2, pp. 349-68.

Tranholm-Mikkelsen, J. (2011) 'The priorities of the Danish Presidency of the EU', European Policy Centre talk, 23 November.

Wammen, N. (2012) 'The Presidency has worked for growth in Europe', Politiken, 1 July. 